\title{
PENERAPAN CARING PERAWAT KOMUNITAS DALAM MEMBERIKAN ASUHAN KEPERAWATAN PADA KLIEN DENGAN PENYAKIT KRONIS
}

\author{
Ninda Ayu Prabasari P ${ }^{1)}$, Made Indra Ayu A ${ }^{2)}$ \\ ${ }^{1,2)}$ Faculty Of Nursing, Widya Mandala Catholic University Surabaya \\ Jalan Raya Kalisari Selatan No 1 Pakuwon City Surabaya, Indonesia \\ nindaayu@ukwms.ac.id
}

\begin{abstract}
ABSTRAK
Caring merupakan esensi keperawatan yang ditujukan untuk perawatan pasien. Jumlah kunjungan pasien yang banyak dan durasi jam operasional puskesmas yang tidak sebanding dengan jumlah perawat yang bertugas, menyebabkan pemberian asuhan keperawatan komunitas kepada klien belum optimal. Penelitian ini menggunakan metode kualitatif dengan pendekatan fenomenologi. Tujuan penelitian untuk mendapatkan data dengan mengeksplorasi penerapan caring oleh perawat komunitas dalam memberikan asuhan keperawatan pada klien dengan penyakit kronis. Populasi penelitian ini adalah perawat yang bertugas di balai pengobatan puskesmas kenjeran dan puskesmas bulak banteng Surabaya sebanyak 7 partisipan yang diperoleh melalui teknik pengambilan sampel purposive sampling. Pengumpulan data dilakukan dengan interview dianalisis menggunakan metode Collaizi. Hasil penelitian didapatkan 10 tema yaitu 1) Konsep caring 2) Konsep asuhan keperawatan 3) Konsep penyakit kronis 4) Lama bekerja 5) Perawatan caring yang dilakukan 6) Usaha untuk meningkatkan caring 7) Hambatan yang di alami 8) Respon saat mengalami hambatan 9) Upaya untuk mengatasi hambatan 10) Manfaat penerapan caring. Caring yang dilakukan oleh perawat komunitas lebih berfokus pada perilaku caring, dimensi caring belum dilakukan secara optimal. Puskesmas sebagai fasilitas kesehatan tingkat pertama hendaknya dapat meningkatkan kualitas pelayanan keperawatan dengan tetap mempertahankan prinsip caring serta kode etik keperawatan dalam memberikan asuhan keperawatan di dalam maupun di luar gedung.
\end{abstract}

Kata kunci: caring, perawat, penyakit kronis

\section{ABSTRACT}

Caring was the essence of nursing that was applied in the process of patient care. The large number of patient visits and the duration of operating time that was not proportional to the number of nurses, causes community nursing care to clients is not optimal. This study used a qualitative method with a phenomenological approach. The research objective was to exploring the application of caring by community nurses in nursing care to chronic diseasesclients. The study population was nurses on duty at two Primary Health Care in Surabaya, that was Kenjeran and Bulak Banteng as many as 7 participants obtained through purposive sampling technique. Data collection was performed by interviews analyzed using the Collaizi method. The results obtained 10 themes, 1) Concept of caring 2) Concept of nursing care 3) Concept of chronic disease 4) Length of work 5) Caring that performed 6) Efforts to improve caring 7) Obstacles experienced 8) Response when experiencing obstacles 9) Efforts to overcome obstacles 10) Benefits of caring application. Caring conducted by community nurses is more focused on caring behavior, caring dimension has not been done optimally. Primary Health Care as a first-level health facility should be able to improve the quality of nursing care while maintaining the caring principle.

\section{Keywords: Caring, Nurse, Chronic Diseases}

\section{PENDAHULUAN}

Penerapan caring oleh perawat di komunitas belum dapat dijelaskan. Caring merupakan dasar bagi perawat untuk dapat menganalisa tindakan keperawatan yang dilakukan baik dan tepat bagi klien yang menjadi acuan dalam perawatan lanjutan dengan kata lain caring merupakan moral ideal profesi keperawatan dimana menunjuk pada kemauan untuk memberikan perawatan 
yang tulus dengan kesungguhan dalam melakukan tindakan merawat klien kesehatan (Kusnanto, 2019) Kualitas pelayanan keperawatan yang baik dapat terwujud dengan pelaksanaan asuhan keperawatan yang professional dengan menerapkan prinsip caring yang merupakan esensi dari profesi perawat. Profesionalisme perawat ditunjukkan oleh pengetahuan dan keterampilan khusus yang mencakup keterampilan intelektual, teknikal, dan interpersonal yang pelaksanaannya harus mencerminkan perilaku caring, yang menjadikan perawat sebagai profesi yang terhormat (Tyas, Dwiantoro, \& Ardani, 2016). Caring tidak hanya mempraktikkan seni perawatan, memberi kasih sayang untuk meringankan penderitaan pasien dan keluarganya, meningkatkan kesehatan dan martabat tetapi juga memperluas aktualisasi diri perawat yang dilakukan dengan penerapan komunikasi efektif dan terapeutik, memberikan tanggapan yang positif serta selalu memberikan dukungan dalam intervensi yang sesuai dengan standar (Kusnanto, 2019)

Asuhan keperawatan meliputi intervensi mandiri, kolaborasi, edukasi dan monitoring. Dalam konteks komunitas perawat memiliki peran penting yaitu care giver, clien advocate, counselor, educator, collaborator, coordinator, change agent, consultant. Asuhan keperawatan di tatanan pelayanan keperawatan komunitas dapat diberikan dalam 2 pelayanan, yaitu: pelayanan di dalam gedung dan pelayanan di luar gedung (kunjungan rumah). Pelayanan di dalam gedung oleh perawat komunitas meliputi pengkajian, penegakan diagnosis keperawatan, pemberian intervensi keperawatan dan evaluasi. Manajemen penyakit kronis dalam pelayanan keperawatan komunitas di dalam gedung sangat erat dengan peran educator yang mendominasi dan peran caregiver. Dalam melaksanakan tugasnya, caring dipersepsikan secara berbeda oleh setiap individu perawat.

Berdasarkan hasil observasi di Puskesmas Kenjeran wilayah Surabaya, tampak bahwa pelayanan keperawatan komunitas di dalam gedung masih belum optimal. Hal ini potensial disebabkan oleh panjangnya daftar antrian pengunjung Puskesmas khususnya Balai Pengobatan dimana perawat komunitas bertugas. Hal ini terlihat dalam kunjungan pasien di Puskesmas Kenjeran dalam satu hari sebanyak $80-100$ pasien. Perawat yang melakukan pemeriksaan bersama dengan dokter berjumlah 1 orang dan terkadang 2 orang sehingga antrian pasien cukup panjang. Kualitas pelayanan yang diukur dengan waktu tunggu terkadang menyebabkan pemberian asuhan keperawatan komunitas kepada klien belum optimal. Aspek yang sering terlupakan adalah penerapan prinsip caring. Dalam konteks manajemen penyakit kronis caring sangat esensial karena berpotensi mempengaruhi tingkat kepatuhan kunjungan yang dapat berdampak pada pencegahan komplikasi penyakit. Pada era Jaminan Kesehatan Nasional (JKN) Puskesmas menjadi ujung tombak fasilitas kesehatan tingkat 1/ pratama. Optimalisasi kinerja perawat dalam memberikan asuhan keperawatan komunitas sehingga klien tidak perlu di rujuk ke faskes yang lebih tinggi.

Memberikan asuhan (caring) secara sederhana tidak hanya sebuah perasaan emosional atau tingkah laku sederhana, karena caring merupakan kepedulian untuk mencapai perawatan yang lebih baik. Perilaku caring bertujuan dan berfungsi membangun struktur sosial, pandangan hidup dan nilai kultur setiap orang yang berbeda pada suatu tempat (Tyas, Dwiantoro, \& Ardani, 2016). Perilaku caring perawat akan terjalin hubungan interpersonal harmonis antara perawat-pasien, membantu dan memenuhi kebutuhan pasien, pada akhirnya dapat memberikan kepuasan kepada pasien. Perilaku caring merupakan esensi keperawatan yang dapat memberi kontribusi positif terhadap kepuasan pasien dalam menerima layanan keperawatan (Potter \& Perry, 2010).

Pelayanan keperawatan saat ini masih kurang memuaskan salah satu penyebab kurangnya perilaku caring perawat. Hal ini dapat diketahui dari penelitian-penelitian yang dilakukan di beberapa rumah sakit antara lain oleh (Rahayu, 2011) penelitiannya tentang faktor-faktor yang berhubungan dengan sikap caring perawat yang dipersepsikan perawat pelaksana di ruang rawat inap RSUP Persahabatan Jakarta, menemukan bahwa 18 $(51,4 \%)$ perawat bersikap caring dan 17 $(48,5 \%)$ perawat bersikap kurang caring. Hal ini merupakan masalah potensial yang dapat mempengaruhi kualitas pelayanan keperawatan karena perawat yang kurang 
caring mempunyai prosentase yang relatif besar. Penelitian lain yang dilakukan oleh (Martiningtyas, Sukesi, \& Kusuma, 2013) di RSUD Dr. H. Soewondo Kendal didapatkan $29.6 \%$ perawat kurang caring terhadap pasien. Penelitian lainnya oleh (Sera, Triyoso, \& Furqoni, 2014) juga mengungkapkan bahwa masih ada $40 \%$ perawat berperilaku tidak caring menurut responden yang merupakan persepsi pasien. Penelitian (Gaghiwu, Ismanto, \& Babakal, 2013) di RSUP Prof.Dr.R.D.Kandou Manado didapatkan 26.7\% perawat berperilaku caring kurang baik. Belum ditemukan penelitian khusus tentang penerapan prinsip caring dalam tatanan pelayanan keperawatan komunitas. Penelitian ini berfokus pada implementasi caring oleh perawat dalam memberikan asuhan keperawatan komunitas.

\section{METODE}

Desain penelitian yang digunakan adalah penelitian kualitatif, pendekatan fenomenologis bertujuan mendapatkan data dengan mengeksplorasi dan menggambarkan pengalaman penerapan konsep caring oleh perawat komunitas dalam memberikan asuhan keperawatan pada klien dengan penyakit kronis melalui interpretasi secara mendalam dari subyektifitas partisipan yang terlibat secara langsung dalam merawat klien dengan penyakit kronis sehingga didapatkan pemahaman dan makna fenomena tersebut bagi perawat. Populasi dalam penelitian ini adalah perawat yang betugas di Balai Pengobatan di Puskesmas Kenjeran dan Puskesmas Bulak Surabaya dimana pemilihan sampel dilakukan melalui purposive sampling yang memenuhi kriteria inklusi dan ekslusi. Jumlah partisipan adalah 7 orang karena pada patisipan ke 7 ditemukannya data jenuh/ saturasi data.

\section{HASIL}

Hasil penelitian tentang penerapan prinsip caring oleh perawat komunitas dalam memberikan asuhan keperawatan pada klien dengan penyakit kronis di tatanan pelayanan keperawatan komunitas didapatkan 10 tema meliputi adalah 1) konsep caring menjadi 2 sub tema yaitu definisi dan perilaku. 2) Konsep asuhan keperawatan didapatkan 2 sub tema yaitu definisi dan tahapan asuhan keperawatan. 3) Konsep penyakit kronis didapatkan 2 sub tema yaitu definisi penyakit kronis, jenis penyakit kronis 4) lama bekerja 5) perawatan caring yang dilakukan didapatkan 2 subtema yaitu perilaku caring, dimensi caring. 6) usaha untuk meningkatkan caring dengan sub tema internet dan buku, seminar. 7) hambatan yang dialami, Sub tema yang didapatkan dalam tema hambatan yang dialami yaitu jumlah kunjungan pasien dan jam pelayanan, tugas lebih dari satu 8) respon saat menghadapi hambatan terdapat 2 subtema yaitu jengkel dan diam. 9) upaya untuk mengatasi hambatan terdapat tiga sub tema yaitu meningkatkan kemampuan, meningkatan kualitas pelayanan, dan sharing dengan tim dan atasan dan untuk tema yang ke 10) manfaat penerapan caring dengan sub tema peningkatan hubungan pasien dan perawat, kepuasan pasien dan kepuasan perawat.

\section{PEMBAHASAN}

\section{1) Konsep Caring}

Partisipan mengungkapkan caring merupakan sikap empati, peduli terhadap kebutuhan pasien, pemberian asuhan keperawatan bukan saat pasien datang ke puskesmas saja tetapi juga saat perawat melakukan home care. Partisipan mengungkapkan perilaku caring seperti empati, ramah kepada pasien yang datang ke balai pengobatan, peduli dengan kebutuhan pasien, melakukan kunjungan rumah pasien, memperhatikan kebutuhan kesehatan yang diperlukan pasien. Hal itu sejalan dengan (Kusnanto, 2019) yang memaparkan bahwa Caring didefinisikan sebagai suatu perilaku atau tindakan yang dilakukan guna memberikan rasa aman baik secara fisik dan emosi kepada orang lain dengan tulus. Caring merupakan hubungan pemberi pelayanan yang bersifat terbuka, dan perawat peduli dengan klien (Potter \& Perry, 2010).

\section{2) Konsep Asuhan Keperawatan}

Asuhan keperawatan dipahami partisipan adalah tindakan yang diberikan kepada pasien sesuai dengan masalah yang dikeluhkannya, proses keperawatan yang dilakukan perawat untuk menyelesaikan 
masalah kesehatan atau keluhan yang dialami oleh pasien dan dilakukan sesuai dengan standar prosedur yang berlaku di Puskesmas. Hasil penelitian tersebut sejalan dengan (Carpenito, 2009) Asuhan keperawatan adalah segala bentuk tindakan atau kegiatan pada praktek keperawatan yang diberikan kepada klien yang sesuai dengan standar operasional prosedur (SOP).

Tahapan asuhan keperawatan yang dipahami partisipan adalah saat pasien datang ke balai pengobatan, pasien dilakukan pengkajian tentang keluhan yang dirasakan, riwayat penyakit sekarang, riwayat penyakit dahulu dan riwayat penyakit keluarga. Perawat melakukan pemeriksaan fisik, menentukan masalah keperawatan, melakukan rencana tindakan dan melakukan tindakan keperawatan baik yang mandiri maupun yang kolaborasi. Perawat memberikan edukasi yang bisa dilakukan dirumah dan edukasi tentang penyakit pasien kemudian perawat mengevalusi tindakan yang sudah dilakukan, didokumentasikan perawat dalam form yang sesuai dengan standar Puskesmas. Hal ini sejalan dengan teori bahwa proses keperawatan adalah suatu metode yang sistematis dan ilmiah digunakan perawat untuk memenuhi kebutuhan klien dalam mencapai atau mempertahankan keadaan biologis, psikologis, sosial dan spiritual yang optimal, melalui tahap pengkajian, identifikasi diagnosis keperawatan, penentuan rencana keperawatan, serta evaluasi tindakan keperawatan (Suarli \& Bachtiar, 2010).

\section{3) Konsep Penyakit Kronis}

Penyakit kronis didefinisikan oleh partisipan sebagai penyakit yang berlangsung terus menerus dan lama penyakit lebih dari 6 bulan, proses penyembuhan memerlukan waktu yang lama dan membutuhkan proses, seseorang dengan penyakit yang mengkonsumsi obat secara terus menerus, pasien yang memiliki nyeri hebat meskipun telah meminum obat nyeri dan mengganggu aktivitas sehari hari pasien. Hal ini sesuai dengan yang dipaparkan bahwa pada saat individu dengan penyakit kronis akan mengalami masalah psikologis berupa perasaan sedih, putus asa dan ketakutan dalam kehidupannya yang pada akhirnya penderita menjadi stress and depresi dalam proses pengobatannya (Agustini, 2016). Rasa sakit yang diderita akan mengganggu aktivitasnya sehari-hari, tujuan dalam hidup, dan kualitas tidurnya (Affleck et al. dalam (Safarino, 2006).

Jenis penyakit kronis dikemukan oleh partisipan sangat bervariasi. Penyakit kronis yang dikemukan adalah hipertensi, diabetes, penyakit degenerative dan penyakit kanker. Jenis penyakit tersebut banyak mereka jumpai di puskesmas saat melakukan asuhan keperawatan kepada pasien yang datang ke balai pengobatan maupun saat melakukan kunjungan rumah. Penyakit tersebut juga merupakan salah satu penyakit terbanyak di Puskesmas. Sejalan dengan hasil penelitian tersebut, menurut BPJS Kesehatan (BPJS, 2014) Penyakit kronis yang disebutkan oleh partisipan seperti hipertensi dan diabetes melitus merupakan dua penyakit kronis yang masuk dalam Program Pengelolaan Penyakit Kronis (Prolanis) yang diprogramkan oleh Badan Penyelenggara Jaminan Kesehatan (BPJS) Kesehatan tahun 2014.

\section{4) Lama Bekerja}

Pengalaman diperoleh perawat saat bekerja di balai pengobatan membuat partisipan merasa semakin tahu saat harus berhadapan dan saat menangani pasien. Pasien yang unik dengan agama, suku, budaya dan keluhan yang berbeda membuat pengalaman yang dirasakan partisipan bervariasi dan menambah pengetahuan dan kemampuan partisipan dalam memberikan pelayanan kepada pasien. Sejalan dengan penelitian (Prihandani, Nopiyani, \& Duarsa, 2015) bahwa terdapat hubungan yang bermakna antara masa kerja dengan perilaku caring perawat pelaksana. Masa kerja dapat mempengaruhi sikap dan perilaku seseorang dalam menunjukkan kinerjanya. Masa kerja yang lebih lama menunjukkan pengalaman yang lebih pada seseorang dibandingkan dengan rekan kerja yang lain (Rivai \& Mulyadi, 2010).

\section{5) Perawatan caring yang dilakukan} Perilaku caring yang dilakukan partisipan saat perawat memberikan pelayanan bersikap ramah, lemah lembut, sopan santun kepada pasien, care, sabar tenang menghadapi pasien, menggunakan komunikasi terapeutik saat dengan pasien dan keluarga pasien, komunikasi verbal dan non 
verbal yang baik kepada pasien. Setiap melakukan tindakan selalu cekatan, cepat, tepat dan terampil memiliki rasa empati, peduli terhadap kebutuhan pasien terutama masalah atau keluhan yang dirasakan saat kunjungan dan memotivasi pasien semangat menjalani pengobatan. Caring harus terwujud melalui sikap peduli, siap sedia untuk memenuhi kebutuhan klien, ramah, bersikap tenang dan memiliki empati terhadap klien dan keluarga. Hal ini termasuk juga dalam peran sebagai perawat untuk selalu bertanggung jawab dan menampilkan sikap professional melalui pembicaraan dan pekerjaan lainnya dalam pendidikan kesehatan, konseling, dan mendengarkan klien (Dedi, Setyowati, \& Afiyanti, 2008).

Dimensi caring yang dilakukan partisipan saat merawat pasien yaitu Maintaining Belief yang sudah dilakukan partisipan yaitu saat bertemu pasien mengucapkan salam, menggunakan komunikasi verbal dan non verbal yang baik, bersifat ramah, kontak mata yang baik, fokus pada keluhan yang dirasakan oleh pasien, mendengarkan setiap keluhan yang dirasakan oleh pasien. (Thomas, Finch, Schoenhofer, \& Green, 2009) mengatakan caring berimplikasi terhadap praktik keperawatan sehingga perawat yang bersikap caring akan berbicara dengan ramah dan santun, mempunyai perhatian, penuh minat dalam menolong klien, dan membina hubungan dalam setiap melakukan tindakannya.

Knowing yang sudah dilakukan partisipan saat pasien datang, perawat menggali informasi terkait keluhan, kesehatan, riwayat penyakit dahulu, sekarang, dan keluarga maupun kondisi lingkungan yang mempengaruhi perubahan kesehatan. perawat bersifat empati dan peduli terhadap kondisi yang dialami pasien. Hasil penelitian (Hafriska \& Kamil, 2017) menyatakan memahami pasien merupakan pemahaman seorang perawat terhadap pasien sebagai acuan melakukan intervensi berikutnya, sehingga antara perawat dan pasien terjalin suatu hubungan yang baik dan saling memahami.

Being with yang sudah dilakukan partisipan adalah perawat hadir menemani pasien, membantu pasien dalam masalah kesehatan yang dirasakan pasien, tidak hanya dilakukan saat di balai pengobatan, tetapi saat kunjungan rumah. Partisipan bekerja sepenuh hati untuk kesembuhan pasiennya. Menurut (Karseno, Dirdjo, \& Muksin, 2015) memaparkan bahwa perawat harus mampu bersikap ramah dan bersahabat, memiliki rasa peka terhadap pasien, dapat berkomunikasi dengan efektif dan mampu memberikan pelayanan yang professional dan yang paling penting dapar menumbuhkan sikap caring untuk kepuasan pasien yang dilayani.

Doing For dilakukan oleh partisipan dengan memberikan tindakan pemeriksaan tanda-tanda vital, melakukan penimbangan berat badan dan pengukuran tinggi badan. Melakukan implementasi sesuai dengan intervensi yang telah di rencanakan misalnya seperti merawat luka, melakukan kunjungan rumah. Penelitian (Nastiti, Kusnanto, \& Ahsan, 2017) menunjukan doing for sangat penting dalam meningkatkan hubungan interpersonal perawat dengan pasien dengan mengetahui apa yang dialami pasien perawat kemudian melanjutkan proses doing for untuk memberikan tindakan terapi dan intervensi untuk pasien.

Enablings diberikan kepada pasien dengan penyuluhan, memberikan leaflet, edukasi sebelum pasien pulang ke rumah dan saat kunjungan rumah. Menurut (Swanson, 1991) Enabling adalah faktor pemungkin berupa emperwomen, dimana perawat memfasilitasi perubahan hidup yang dirasakan oleh klien, seperti memberi informasi, mencoba cara penyelesaian masalah, memberi dukungan, mampu memberikan umpan balik kepada klien saat berkomunikasi. Menurut (Kusnanto, 2019) peran perawat adalah Caregiver, Client advocate, Counsellor, Educator, Collaborator, Coordinator, Change agent dan Consultant. Perawat mempunyai tanggung jawab mencakup aspek bio-psikososial-kultural dan spiritual dalam memberikan asuhan keperawatan pemenuhan kebutuhan dasar klien dengan menggunakan pendekatan proses keperawatan.

\section{6) Usaha untuk meningkatkan caring}

Partisipan menggungkapkan lebih mudah mendapatkan informasi dengan menggunakan internet, ketika kesulitan atau ingin menambah pengetahuan dengan mudah untuk memperoleh informasi, tetapi tetap berhati-hati saat menggunakan internet dan tidak sembarang percaya dengan artikel. 
Penggunaan internet dapat mempermudah mendapatkan informasi secara cepat, dan dapat meningkatkan minat untuk membaca. Menurut (Pibriana \& Ricoida, 2017) mahasiswa berpersepsi internet akan berdampak positif terhadap pembelajaran dan pekerjaan mereka dan membantu prospek pekerjaan dimasa akan datang. Selain itu partisipan ada juga yang mengikuti seminar. Pelatihan dan seminar mempunyai hubungan yang bermakna dengan perilaku caring perawat. Hasil penelitian didukung hasil penelitian (Sutriyanti, 2009) yang menunjukkan ada pengaruh yang bermakna antara pelatihan caring dengan kepuasan pasien terhadap perilaku caring perawat.

Buku keperawatan dan kesehatan juga menjadi salah satu usaha partisipan utuk meningkatakan caring. Ungkapan yang mengatakan bahwa buku merupakan jendela dunia memang benar adanya. Buku merupakan sarana awal untuk mendapatkan pengetahuan. Hal ini sesuai dengan penelitian (Igiany, Sudargo, \& Widyatama, 2016) yang mendapatkan hasil bahwa penggunaan buku berpengaruh secara signifikan terhadap peningkatan pengetahuan dibanding video.

\section{7) Hambatan yang di alami}

Patisipan mengungkapkan jumlah kunjungan pasien ke balai pengobatan setiap harinya antara 100-150 pasien dengan jam pelayanan 5-6 jam. Keluhan dirasakan apabila dalam satu hari hanya ada satu perawat dan satu dokter dalam balai pengobatan, ini berhubungan dengan tugas lebih dari satu yang di lakukan perawat. Tugas tambahan lain seperti Tim Gerak cepat, ambulan 112, kegiatan di sekolah, kegiatan di posyandu balita dan lansia, kunjungan rumah dan tugas yang lainnya membuat perawat di balai pengobatan menjadi sedikit karena harus berbagi tugas di tempat yang lain.

Peraturan Menteri Kesehatan Nomor 75

Tahun 2014 tentang Pusat Kesehatan Masyarakat, jumlah minimal tenaga perawat sebanyak 5 orang, sedangkan di Puskesmas Kenjeran hanya 3 orang dan di Puskesmas Bulak Banteng hanya 4 orang yang berarti jumlah perawat masih kurang sehingga menambah beban kerja perawat. Tugas tambahan perawat Puskesmas di luar gedung menjadi beban kerja tersendiri. Menurut (Rizcarachmakurnia, Wigati, \& Sriatmi, 2017) perawat di Puskesmas memiliki tupoksi yang sama yaitu melakukan pelayanan asuhan keperawatan, melakukan kegiatan administrasi seperti pencatatan, dan dokumentasi data pasien. Selain itu perawat terbebani juga dengan target pencapain program yang cukup tinggi, perawat juga mengungkapkan adanya tugas tambahan dan tugas lain di Puskesmas Pembantu.

\section{8) Respon saat mengalami hambatan}

Terkadang partisipan jengkel dengan pasien yang tidak mengerti prosedur, pasien yang mau minta dilayani terlebih dahulu ataupun mengantri lama dan belum dipanggil masuk ke balai pengobatan. Ada juga partisipan yang diam dan tersenyum saat ada pasien yang masih tidak mengerti tentang prosedur pelayanan, antrian masuk, yang marah atau komplain ke perawat, walaupun sudah dijelaskan berulang kali oleh perawat. Perawat tetap bekerja secara professional walaupun mengalami kendala dan berusaha menegendalikan diri supaya tetap professional saat memberikan asuhan keperawatan. Hal ini sesuai dengan penelitian (Purnama, Satrianegara, \& Mallapiang, 2017) bahwa sebagian besar perawat di Puskesmas mengalami peningkatan tingkat stres dikarenakan stimulus atau situasi yang menimbulkan stres pada lingkungan kerja, walaupun begitu kualitas kinerja responden dalam kategori baik. Adanya tuntutan pasien untuk segera dilayani ditengah banyaknya pekerjaan perawat di Puskesmas menjadi faktor pemicu stress perawat, namun perawat tetap dapat menjalankan tugas secara optimal.

\section{9) Upaya untuk mengatasi hambatan}

Saat partisipan menghadapi kendala keterbatasan jumlah perawat dengan jumlah kunjungan yang banyak. Perawat melakukan pengkajian fokus, cepat dan tepat supaya tidak terjadi antrian panjang, pasien mendapatkan pelayanan cepat dan masalah kesehatan dapat segera ditangani. Partisipan juga meningkatkan kualitas layanan, seperti asuhan keperawatan tidak hanya dilakukan di balai pengobatan tetapi juga melalui kunjungan rumah yang terjadwal dan teratur.

Puskesmas menyediakan lembar umpan balik berupa saran, kritik dan masukan setiap kali pasien datang berobat ditujukan mengevaluasi pelayanan yang diberikan untuk 
peningkatan kualitas layanan yang diberikan. Sharing dengan tim dan atasan, dilakukan oleh patisipan jika menghadapi kendala, masalah selama pelayanan saat di balai pengobatan dan kunjungan rumah.

Menurut (Karseno, Dirdjo, \& Muksin, 2015) Kemampuan komunikasi adalah hal paling penting dalam berhubungan dengan pasien, dan merupakan kompetensi kunci serta menggambarkan profil seorang perawat yang wajib digunakan dalam pelayanan keperawatan. Pelayanan dan asuhan keperawatan yang diberikan kepada klien merupakan bentuk pelayanan professional bertujuan untuk membantu klien dalam pemulihan dan peningkatan kemampuan dirinya melalui tindakan pemenuhan kebutuhan klien secara komprehensif dan berkesinambungan sampai klien mampu untuk melakukan kegiatan rutinitasnya tanpa bantuan

\section{0) Manfaat penerapan caring}

Meningkatnya hubungan pasien perawat yang terjalin secara professional, partisipan mengungkapkan terbantu dengan mengenal banyak pasien yang datang berobat ke puskemas. Tidak jarang perawat dibantu oleh pasien yang ditemui di jalan saat mencari alamat pasien lain, ketika hubungan profesionalisme terjalin proses penyebuhan dan proses asuhan keperawatan saat kunjungan rumah juga semakin membaik. Pasien mendapatkan proses penyembuhan yang cepat, mendapatkan penanganan yang baik untuk masalah kesehatan. Perubahan kesehatan ke arah lebih baik, membuat kepuasan pasien dan kepuasan perawat. (Wolf, Miller, \& Devine, 2010) yang menyatakan bahwa kinerja staf perawat termasuk perilaku caring dapat memberikan kontribusi besar terhadap kualitas pengalaman pasien selama dilakukan perawatan. Kepuasan pasien adalah keluaran (outcome) layanan kesehatan. kepuasan pasien merupakan salah satu tujuan dari peningkatan layanan kesehatan (Wright, Causey, Dienemann, Guiton, Coleman, \& Nussbaum, 2013).

\section{KESIMPULAN}

Partisipan sudah melakukan caring saat memberikan asuhan keperawatan pada klien dengan penyakit kronis. Caring yang diberikan ke pasien lebih dominan pada perilaku caring, dimensi caring dilakukan oleh partisipan sesuai dengan tahapannya tetapi masih ada beberapa yang belum dilakukan secara mendetail.

\section{SARAN}

Hasil penelitian ini memberikan rekomendasi bagi pelayanan keperawatan di Puskesmas untuk tetap mempertahankan prinsip caring serta kode etik keperawatan dalam memberikan asuhan keperawatan sedangkan untuk pengembangan ilmu keperawatan melalui penelitian dapat dilakukan melalui pengembangan penelitian tentang perilaku caring perawat yang dapat dilihat dari sudut pandang pasien dan dikaitkan dengan tingkat kepuasan pasien maupun perawat dalam proses pemberian asuhan keperawatan.

\section{DAFTAR PUSTAKA}

Agustini. (2016). Self Efficacy dan Makna Hidup pada Penderita Jantung Koroner Samarinda. Ejournal Psikologi Volume 4 Nomor 4 , 419-430.

BPJS, K. (2014). Panduan Praktis Prolaris (Program Penggelolaan Penyakit Kronis). Jakarta : BPJS Kesehatan.

Carpenito, L. (2009). Buku Asuhan Keperawatan . Jakarta : EGC.

Dedi, B., Setyowati, \& Afiyanti, Y. (2008). Perilaku Caring Perawat Pelaksana di Sebuah Rumah Sakit di Bandung : Study Grounded Theory. Jurnal Keperawatan Indonesia Volume 12 No 1 .

Gaghiwu, L., Ismanto, A. Y., \& Babakal, A. (2013). Hubungan Perilaku Caring Perawat dengan Stress Hospitalisasi pada Anak Usia Toddler di Irna E BLU RSUP Prof. Dr. R.D. Kandou Manado. E Journal Keperawatan (e-Kp) Volume 1 Nomor 1 .

Hafriska, C., \& Kamil, H. (2017). Perilaku Caring Perawat dengan Pendekatan Teori Swanson di Ruang Rawat Inap . Jurnal Ilmiah Mahasiswa Fakultas Keperawatan 2 (3) , 1-6.

Igiany, P. D., Sudargo, T., \& Widyatama, R. (2016). Efektifitas Penggunaan Video dan Buku Bergambar dalam meningkatkan Pengetahuan, Sikap, dan Ketrampilan Ibu Mencuci Tangan 
memakai Sabun. Berita Kedokteran Masyarakat Vol 32 (3) .

Karseno, Dirdjo, M., \& Muksin. (2015). Hubungan Pelaksanaan Komunikasi Terapeutik dan Kualitas Pelayanan Keperawatan dengan Kepuasan Pasien di Ruang Tulip Rawat Inap Penyakit Dalam Rumah Sakit Penajam Paser Utara. Kalimantan Timur: Http://dispace.umkt.ac.id/handle/463.20 $17 / 1139$.

Kusnanto. (2019). Perilaku Caring Perawat Profesional. Surabaya: Pusat Penerbitan dan Percetakan Universitas Airlangga (UAP).

Martiningtyas, L., Sukesi, N., \& Kusuma, M. (2013). Hubungan Caring Perawat Pelaksana dengan Kepuasan Pasien di Ruang Rawat Inap RSUD Dr. H. Soewondo Kendal. Jurnal Ilmu Keperawatan dan Kebidanan .

Nastiti, A., Kusnanto, \& Ahsan. (2017). Pelatihan Caring dengan Model Partisipatif untuk Peningkatan Kinerja Perawat dan Mutu Layanan Keperawatan. Jurnal Penelitian Kesehatan Suara Forbes 7 (4) , 216224.

Pibriana, D., \& Ricoida, D. I. (2017). Analisis Pengaruh Penggunaan Internet terhadap Minat Belajar Mahasiswa. Jurnal Teknik Informatika dan Sistem Informasi (Jatisi).

Potter, P., \& Perry, A. (2010). Fundamental Keperawatan Edisi 7. Jakarta: EGC.

Prihandani, I., Nopiyani, N., \& Duarsa, D. (2015). Hubungan Faktor Individu dan Budaya Organisasi dengan Perilaku Caring Perawat Pelaksana di Ruang Rawat Inap Rumah Sakit Umum Ganesha Gianyar. Public Health and Preventive Medicine Archive Volume 3 Nomor 1 .

Purnama, D. A., Satrianegara, M. F., \& Mallapiang, F. (2017). Gambaran Faktor Psikososial Terhadap Kinerja Pada Petugas Kesehatan di Puskesmas Kassi-Kassi Kota Makasar. Higiene Jurnal Kesehatan Lingkungan , 106113.

Menteri Kesehatan Republik Indonesia. Peraturan menteri kesehatan Republik Indonesia No. 75 Tahun 2014, Pub. L.
No. 75 (2014). Indonesia: Menteri Kesehatan Republik Indonesia. Retrieved from http://aspak.yankes.kemkes.go.id/berand a/wp-

content/uploads/downloads/2015/03/PM K-No.-75-ttg-Puskesmas.pdf

Rahayu, S. (2011). Faktor Faktor yang berhubungan dengan sikap caring yang dipersepsikan oleh Perawat Pelaksana di Ruang Rawat Inap RSUP Persahabatan Jakarta. Jakarta: Program Magister Ilmu Keperawatan FIK UI.

Rivai, V., \& Mulyadi, D. (2010). Kepemimpinan dan Perilaku Organisasi. Jakarta : PT Raja Grafindo Persada.

Rizcarachmakurnia, N., Wigati, P. A., \& Sriatmi, A. (2017). Analisis Beban Kerja dan Kebutuhan Tenaga Perawat di Puskesmas Poncol Kota Semarang . Jurnal Kesehatan Masyarakat (JKM eJournal) Vol 5 (3) , 26 - 32.

Safarino, E. (2006). Health Psychology: Biopsychosocial Interactions. USA: John Wiley \& Sons.

Sera, T., Triyoso, \& Furqoni, P. (2014, September 14). Hubungan Perilaku Caring Perawat dengan Kepuasan Keluarga Pasien Jiwa di IRJ Provinsi Lampung tahun 2014. Jurnal Kesehatan Holistik, 186-191.

Suarli, \& Bachtiar. (2010). Manajemen Keperawatan dengan Pendekatan Praktis. Jakarta : Erlangga.

Sutriyanti, Y. (2009). Pengaruh Pelatihan Perilaku Caring Perawat terhadap Kepuasan Pasien dan Keluarga di Ruang Rawat Inap RSUD Curup Bengkulu . Jakarta: FIK UI.

Swanson, K. (1991). Empirical Development of a Middle Range Theory of Caring . Nursing Research .

Thomas, J. D., Finch, L. P., Schoenhofer, S. O., \& Green, A. (2009). The Caring Relationship Created Nurse Practitioners and the Ones nursed: Implication for Practice . Advanced Practice Nursing eJournal 4(4) .

Tyas, A. P., Dwiantoro, L., \& Ardani, M. (2016). Hubungan Persepsi Perawat Pelaksana tentang Total Rewards 
dengan Perilaku Carative Caring di Ruang Inap RSUD Dr. Soegiri Lamongan. Semarang: http://eprints.undip.ac.id/51266/1/ANE STASIA TESIS full text.pdf.

Wolf, Z. R., Miller, P. A., \& Devine, M. (2010). Relationship Between Nurse Caring and Patient Satisfaction in Patients Undergoing Invasive Cardiac Procedures. Medsurg Nursing , 391.

Wright, G., Causey, S., Dienemann, J., Guiton, P., Coleman, F. S., \& Nussbaum, M. (2013). Patient Satisfaction with Nursing Care in an Urban and Sub Urban Emergency Department . Journal of Nursing Administration, 502-508. 